Article

\title{
Food Preferences in Finland: Sustainable Diets and their Differences between Groups
}

\author{
Elina Lehikoinen ${ }^{1, *}$ and Arto O. Salonen ${ }^{2,3} \mathbb{D}$ \\ 1 Water and Development Research Group, School of Engineering, Aalto University, P.O. Box 15200, \\ FI-00076 Aalto, Finland \\ 2 Faculty of Social Sciences and Business Studies, University of Eastern Finland, P.O. Box 1627, \\ FI-70211 Kuopio, Finland; arto.salonen@uef.fi \\ 3 Finnish National Defence University, PL 7, 00861 Helsinki, Finland \\ * Correspondence: elina.lehikoinen@aalto.fi
}

Received: 20 December 2018; Accepted: 20 February 2019; Published: 27 February 2019

check for updates

\begin{abstract}
The world is facing the great challenge of how to feed the increasing and wealthier population sustainably in the future, with already limited natural resources. The existing literature reveals the negative impacts of animal-based diets, and thus global diet changes are required to ensure future food availability. Nevertheless, it is important to acknowledge that food consumption is more than caloric intake-it is based on personal preferences. We assessed how sustainable food choices vary among Finnish citizens. The respondents $(n=2052)$ answered nine statements about their consumption behavior. We applied quantitative and qualitative methods, and our results indicate that favoring plant-based diets was the highest among people under 30 and above 60 years old. Middle-aged men with high incomes was the most reluctant group to adopt sustainable diets. Health-related issues and origin of food were the most preferred reasons for food choices, while environmental awareness was ranked lower. The key to mainstream sustainable diets lies in the co-benefits - transition towards more sustainable diets among Finns could be possible, if people felt that they can combine the selfish, hedonistic factors (e.g., health, weight loss) and altruistic factors (e.g., ecological benefits) in their everyday diets.
\end{abstract}

Keywords: animal-based diets; consumer behaviour; co-benefits; diet change; food culture; plant-based diets; sustainable diets

\section{Introduction}

The world is facing a great challenge of how to feed the population sustainably in the future. Natural resources for food production are already scarce in many parts of the world, and the population is expected to reach 9 or even 10 billion by 2050 [1,2], which exacerbates the pressure on an already worrying global situation. Fortunately, there are existing studies that present how to increase food production sustainably with the current resources. Dietary changes towards healthier and plant-based diets, improvements in technologies and management, reductions in food loss and waste, are assessed to be the main contributors to increasing the global food availability without expanding the agricultural land use (see e.g., [3,4]).

In this study, we focus on diet change, since for citizens, it is the most effective and easiest way to influence the environment. Food and eating combine the elements of nature and culture [5], but the way we are eating changes constantly [6]. Wahlqvist and Lee [7] explained that the sense of local and regional food culture have existed throughout human development. In the past, the food culture altered relatively slowly, but current global phenomena, such as rapid population changes, global trade, displacements and migrations, and variances in affordability, has accelerated these 
changes. Nevertheless, it is important to understand that food consumption is about more than just nutrition-eating enjoyment is based on manifold personal preferences, and attitudes might greatly differ among the people living in regions where there are multiple meal options and financial means to choose the preferred diet [8].

Hartmann and Siegrist [9] highlighted that a behavioral change is needed in more prosperous countries to reduce substantial environmental damage caused by food consumption. Sabate and Soret [10] also specified that the drastic diet changes are complex, which implicates behavioral and policy challenges at many levels. Therefore, dietary recommendations should be tailored to regional conditions for preserving cultural eating habits and contributing to more environmentally friendly consumption [11]. There are already Western country-scale studies about citizens' behaviors and attitudes towards meat consumption and sustainable diets (see e.g., Belgium: [12,13], Finland: [14,15], Germany: [16], Netherlands: [17,18], Scotland: [19], United States: [20]). However, the information about nutrition, food safety and dietary recommendations is increasing and changing constantly, and thus diet changes among citizens constitute a heterogeneous and dynamic research area.

This present study supplements the existing knowledge about the people's dietary preferences, and assesses the potential to mainstream diet changes towards a more sustainable direction at a country level. In the long term, the demand for livestock is projected to grow by $70-80 \%$ between 2005 and 2050 [21,22], and it is crucial to change this direction. For example, in Nordic countries, the consumption of meat has almost doubled in the past 50 years, being one of the highest in the world [11,21]. Our research focuses on Finland-a typical affluent country with a low population and high animal protein consumption [23]. Even though Finnish meat consumption ( $\left.\mathrm{kg} \mathrm{cap}^{-1} \mathrm{year}^{-1}\right)$ is slightly lower than in other Western European countries and stabilized in the recent years [24], the consumption is still beyond the national recommendations $[25,26]$. Since there is not only one single reason as to why people would choose less animal-based and more plant-based diets [9], we study the variance of different socio-demographic characteristics, such as age, gender, living area and income, as they relate to dietary habits. In addition, we also assess personal preferences, environmental awareness, and activity to influence when making food-related decisions, in an order to understand the main drivers and key obstacles related to choosing plant-based and domestic meals.

\section{Diet Choices in Everyday Life}

\subsection{Sustainable Diets Regarding People and the Environment}

Sustainable diets are described as consumption that is nutritious, safe and healthy in both quantity and quality. The food also needs to be economically, environmentally, socially and culturally sustainable for the present and future generations. For food to be sustainable, it should not threaten the needs of others but should be protective and respectful of biodiversity and ecosystems (see e.g., $[10,27,28])$. There are four main factors that make plant-based diets recommendable for transitioning to a sustainable society: global food security, human health, environment and animal welfare [29].

Sabate and Soret [10] state that the current food consumption and environmental changes, food security and food sustainability are on a collision course. The world has enough food, but it is produced and distributed unevenly. To find a balance in this situation, several consumer studies have been published in relation to ecological food choices and consumption, including more sustainable food consumption and plant-based diets (see e.g., [3,4,13,30-36]).

The increasing knowledge about negative health issues associated with meat consumption has concerned nutrition experts. Despite meat being an easy and important way to meet dietary protein requirements [37,38]—processed red meat intakes can contribute to increases in total mortality, cancer mortality, and cardiovascular disease mortality as well as the risks of contracting type 2 diabetes [39-43]. Even though the WHO (World Health Organization) and the World Cancer Research Fund (WCRF) recommend plant-based diets, they also acknowledge that a moderate amount of red meat can be acceptable if it is not processed $[44,45]$. 
At the same time, livestock production consumes considerable volumes of water [46] and occupies significant areas of farmland [47] that could be used more efficiently for the cultivation of alternative protein resources. In addition, livestock production is a substantial greenhouse gas producer and contributor to eutrophication of waterways [47], among other negative environmental impacts. Yet, it is central to acknowledge the current importance of meat protein and therefore, more attention needs to be paid for the suitable production areas of livestock where there is a surplus of water and land $[48,49]$.

Despite the harmful impacts, meat consumption is increasing globally as the population is getting wealthier [23]. At the global level, the main drivers for the increased meat intake are manifold, such as an increased income, urbanization, changes in trade policies and consumer attitudes [50]. At the same time, the main reasons to reduce meat intake are equally multiple, including population growth, ecosystem deterioration and public health risks [2,39,51,52].

\subsection{Features Behind Choosing Sustainable Diets}

\subsubsection{Motivation for Personal Food Consumption}

Hartmann and Siegrist [9] stated that citizens' preferences form a complex net with multiply reasoning for personal diets, especially in the western countries. Järvelä et al. [14] explained that people often describe their food choices in terms of avoiding or favoring. This division itself already includes what one considers to be good or bad choices. The strategy of avoiding seeks to eliminate the threats of food quality and safety from own's eating habits. The strategy of favoring seeks to consume food that is believed to be safe and health-promoting [14].

There are clear differences in meat consumption between women and men. In general, women have expressed more concern for the environment [9,53-55] and are more likely to reduce their meat consumption $[18,35,56,57]$. Men appear to be less willing to reduce their meat consumption, and in addition, they prefer larger meat portions [17,35]. De Boer and Aiking [56] discovered that people who prefer plant-based meals and white meat also have a lower appreciation for the taste of red meat. More precisely, favoring plant-based diets is linked with concerns over animal welfare, and favoring white meat is linked with pickiness about meat [56]. Even though people have different attitudes towards meat production, often it is not strong enough to directly influence consumption behavior [6].

Research also suggests that older people have more sustainable ways of living than younger citizens [58,59], and meat consumption is expected to decline with age [60-62]. The reasons behind the decline in meat consumption can be manifold such as the changes of taste, higher cost of meat, poor dentition, digestive issues or simply personal preferences. Increasing health awareness and concern might eventually even lead to a declining appetite [62].

Improved incomes or lower food prices have led to the increased consumption of animal-based diets and processed foods [50,63], but this might not directly correlate with personal choices. It seems that people with higher levels of education (often also correlated with higher incomes), have lower levels of meat consumption [62]. Thus, income is not a straightforward determinant of food consumption. At the same time, rapid urbanization has impacted food consumption patterns significantly. Globally urban areas often are characterized by higher caloric intake, including higher consumption of animal products and food fat $[50,64]$, but this might refer mainly to the urban poor.

\subsubsection{Environmental Awareness in Food Choices}

Hartmann and Siegrist [9] discovered that the environmental impacts of food consumption are often unknown to people, especially in various Western countries. Only a small minority of citizens are aware that a plant-based diet is more environmental friendly than an animal-based diet [16]. It also seems that even if citizens acknowledge the negative environmental impact of meat consumption, generally there is an underestimation of it $[12,17]$. The negative environmental impacts are often 
projected to packaging, food waste, transportation of food, production and processing of the food, rather than to actual meat consumption $[19,50]$.

Individuals often can adapt more easily to the environmentally friendly behavior that is effortless or has a low cost (e.g., recycling), than to behavior that is potentially more inconvenient or has a high cost (e.g., vegetarian diet) $[53,65,66]$. Also, people might feel that they have already reduced their meat consumption and hence do not see the reason to change their dietary habits any further [19]. Only a minority of the citizens are willing to change their diets towards a more plant-based one for ecological reasons, while health-related reasons are more prominent $[9,19]$. Salonen et al. [67] discovered that sometimes pursuing personal interests is a strong driving force to choosing diets.

\subsubsection{Activity to Influence on Food Consumption}

The world is changing constantly, along with the various information regarding food, diets and dietary recommendations. Holm and Palojoki [68] stated that the problem is not the lack of information, rather the difficulty to digest it all. People often know a lot about food-related issues, but at the same time, they acknowledge the inability to implement those in their daily routines [14]. Järvelä et al. [14] also discovered that citizens often feel overwhelmed by the increasing new information that conflict with the previous information, or there might be even feelings of despair and doubt if citizens' personal actions would have any significant difference [19]. In addition, some citizens are not willing to change their meat consumption habits because they are sceptical about the scientific relevance, or have formed a mistrust towards the constantly changing information flow [69].

It seems that changes in taste and preferences are usually linked with long-term shifts, while the short-term changes are more frequent and often affected by negative information [62]. The popularity of local, sustainable and organic food has increased over recent years [50], and the origin of food is considered to be important to people because these foods are believed to be simply better [6]. Organic and local foods are commonly associated with economic benefits and transparency [70], as well as health and freshness of food [20]. Yet, it is worth noting that the benefits are focused more on personal gains rather than concerns about the environment [20]. Järvelä et al. [14] added that, for example in Finland, if the statements about the importance of the local food were fully put into practice, the selection in stores would be different that it is currently. Therefore, we can make only limited assumptions based on the surveys. Overall, the knowledge about more sustainable food choices is related with a higher willingness to change meat consumption behavior $[9,17,71]$.

\subsection{Research Questions for this Study}

In this paper, we focus on sustainable diets from citizens' perspectives, and study the potential transition towards more sustainable diets. Our research questions are: (a) How do sustainable food choices vary among Finnish citizens' everyday lives? and (b) What kind of transition potential towards more sustainable diets can be identified in Finland? We analyze a variation of age, gender, living area and net-income because socio-demographics factors other than gender or cultural background have rarely been examined [9]. Sabate and Soret [10] stated that food behavior is determined also by other factors than just socio-demographics characteristics, such as attitudes, norms and culinary traditions. Therefore, in order to comprehend the driving forces behind Finnish citizens' dietary habits, we also assess personal preferences, environmental awareness and activity to influence everyday food choices.

\section{Materials and Methods}

Data used in this research was part of a wide national survey that focused on Finnish citizens' sustainable behavior, and our research used the data related to sustainable diet choices. Figure 1 presents how our study was conducted-it was divided into quantitative and qualitative analyses. The quantitative analysis focused on variances between different groups of citizens when choosing a sustainable diet, and the qualitative analysis studied the main drivers and key obstacles when choosing plant-based meals. 


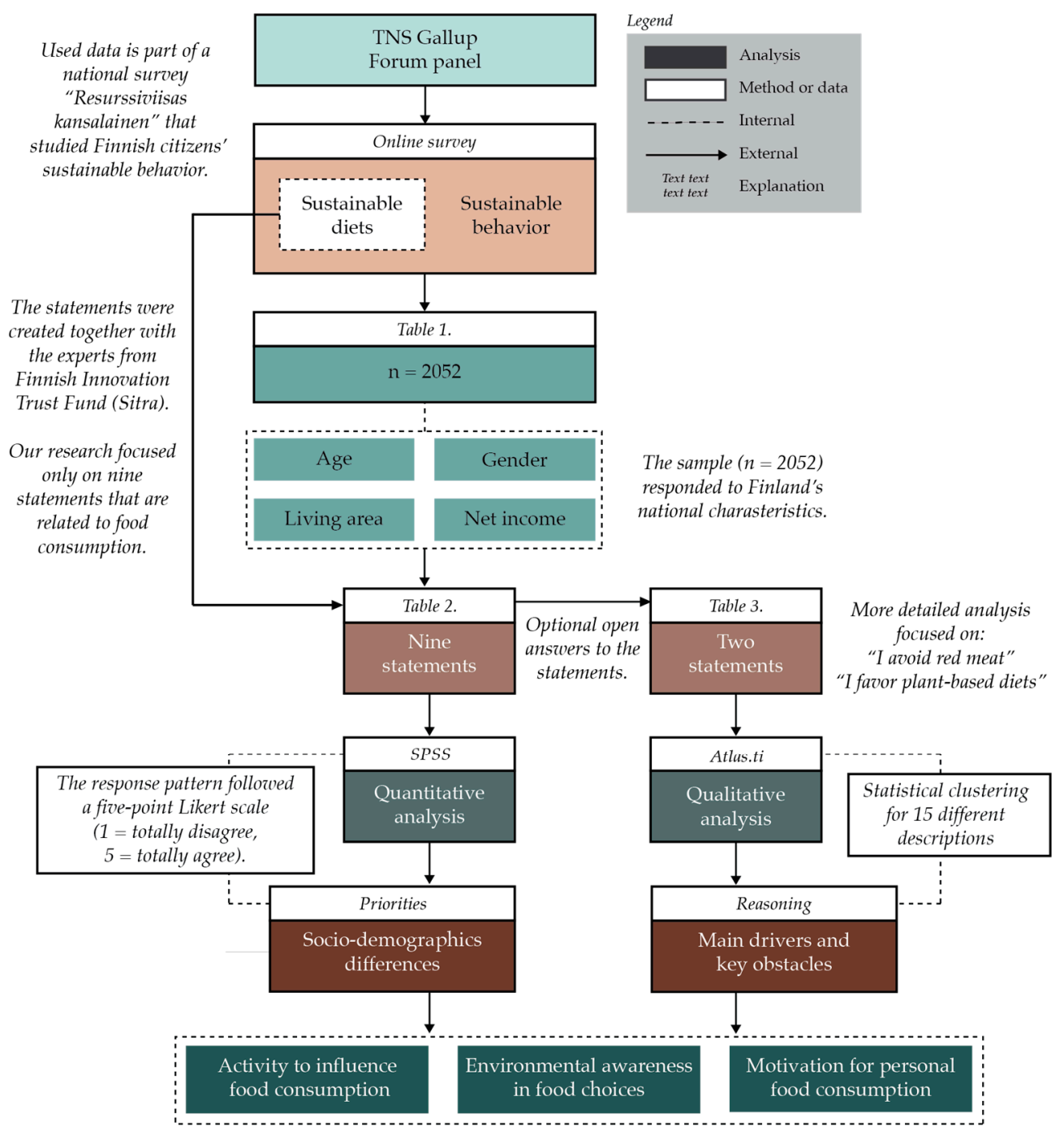

Figure 1. Flowchart of the study. Our quantitative analysis focuses on variances between different groups of citizens when choosing a sustainable diet, and the qualitative analysis studies the main drivers and key obstacles to choosing plant-based meals.

A sample $(\mathrm{n}=2052)$ was collected in April 2017 via an online questionnaire from the TNS Gallup Forum-panel. The panel serves different national research surveys containing 40,000 respondents that represents the population of Finland (18-79 years old), excluding Åland region, while the population of Finland is around 5.5 million people [72]. Table 1 presents socio-demographic characteristics of the sample (left) and Finland's national socio-demographics (right) for the year 2017 [72-77] when the survey was conducted.

Table 1. Socio-demographics characteristics of the sample $(n=2052)$ and Finland's socio-demographics for the year 2017 [72-76].

\begin{tabular}{lcc|c}
\hline $\begin{array}{c}\text { Sample's } \\
\text { Socio-Demographics }\end{array}$ & $\mathbf{n}$ & $\%$ & $\begin{array}{c}\text { Finland's } \\
\text { Socio-Demographics }\end{array}$ \\
\hline $\begin{array}{l}\text { Gender }(\mathrm{n}=2052) \\
\text { Female }\end{array}$ & 1048 & 51.1 & $50.7 \%$ \\
Male & 1004 & 48.9 & $49.3 \%$ \\
\hline Age $(\mathrm{n}=2052)^{1}$ & & & \\
$<30$ & 210 & 10.2 & $33.9 \%$ \\
$30-39$ & 236 & 11.5 & $12.8 \%$ \\
\hline
\end{tabular}


Table 1. Cont.

\begin{tabular}{lcc|c}
\hline $\begin{array}{c}\text { Sample's } \\
\text { Socio-Demographics }\end{array}$ & $\mathbf{n}$ & $\mathbf{\%}$ & $\begin{array}{c}\text { Finland's } \\
\text { Socio-Demographics }\end{array}$ \\
\hline $40-49$ & 429 & 20.9 & $12.0 \%$ \\
$50-59$ & 310 & 15.1 & $13.3 \%$ \\
$60-69$ & 529 & 25.8 & $13.4 \%$ \\
$>70$ & 338 & 16.5 & $14.7 \%$ \\
\hline Living area (n=2052) & 521 & 25.4 & \\
Metropolitan area & 1062 & 51.8 & $20.8 \%$ \\
Other cities/towns & 469 & 22.9 & $50.1 \%$ \\
Countryside & 189 & 11.2 & $29.1 \%$ \\
\hline Net income of the respondent in $€(\mathbf{n}=\mathbf{1 6 9 4})$ & \\
$<10,000$ & 331 & 19.5 & $17.9 \%$ \\
10,001-20,000 & 428 & 25.3 & $23.1 \%$ \\
20,001-30,000 & 342 & 20.2 & $16.5 \%$ \\
30,001-40,000 & 210 & 12.3 & $9.4 \%$ \\
$40,001-50,000$ & 194 & 11.5 & $12.9 \%$ \\
$>50,000$ & &
\end{tabular}

${ }^{1}$ The sample accounts for respondents only from the age group between 18-79 years old, while the national socio-demographic characteristics present the whole age group, starting from 0 years old until $>100$ years old [74].

The statements were developed together with the experts from the Finnish Innovation Fund Sitra. The original questionnaire had a wide range of statements regarding different attitudes and actions that related to sustainable consumption and sustainable behavior. The unambiguity of the claims in the questionnaire was pretested by students of Metropolia University of Applied Sciences, Finland. On the basis of the feedback, ambiguous claims were removed or reduced to more unambiguous ones. The response pattern followed a five-point Likert scale ( $1=$ totally disagree, $5=$ totally agree).

Our analysis focused on nine statements regarding sustainable food consumption in citizens' everyday life (Table 2). In order to identify variances between groups, we applied a one-way ANOVA with post hoc procedures by SPSS. Levene's test results were significant which means that the assumption the homogeneity of variance was broken. According to Tabachnick and Fidell [78] problems created by unequal group sizes, however, are relatively minor. Moreover, we applied Brown-Forsythe $F$ because it gets around this challenge by weighting the group variances by the inverse of their sample sizes [79].

Table 2. The statements that the participants were asked to respond to (a five-point Likert scale).

\begin{tabular}{cc}
\hline \multicolumn{1}{c}{ Category } & Statements \\
\hline Motivation for personal food consumption & $\begin{array}{c}\text { I favor a plant-based diet } \\
\text { I avoid eating red meat (beef, pork, lamb) } \\
\text { I like to try new healthy and environmental friendly foodstuff }\end{array}$ \\
\hline Environmental awareness in food choices & I favor locally produced food \\
Activity to influence food consumption & $\begin{array}{c}\text { I take into account the origin of food while shopping } \\
\text { I choose a pro-climate meal in a restaurant }\end{array}$ \\
& I actively influence what I eat \\
& I try to minimize the environmental cost of my diet \\
\hline
\end{tabular}

The respondents were also able to explain in more detailed why they considered the specific statement-a way of food consumption — to be important for them. By analyzing open answers based on the statements, it was possible to get complementary information to be added to the quantitative analysis. The qualitative analysis was done to two statements in the questionnaire: "I avoid eating red meat (beef, pork, lamb)" and "I favor a plant-based diet". 
Initially, the statement related to avoiding meat had 421 open answers but after cleaning the data, we analyzed 326 open answers. Also, the statement related to favoring a plant-based diets initially had 632 open answers but after cleaning the data, we analyzed 417 open answers. The neglected open answers either stated plain "yes" or " $n$ " and did not provide any additional information, specified unwillingness to answer the open question or the content of the answer was not clear. Many of the neglected open answers also included descriptive information about the content of meals, time-related specifics, overall willingness to change consumption habits without further explanation or otherwise included information that did not respond to the statements.

The open answers were clustered according to Table 3 by using Atlas.ti. The same clustering was used for both statements in an order to assess the differences and similarities in avoiding red meat or favoring plant-based diets. Often the open answers had multiple descriptions, and hence there were more answers related to statements than the overall number of open answers. The multiple reasons were analyzed with a code co-occurrence tool. The c-coefficient value indicates the strength of the relation between two codes similar to a correlation coefficient. The c-coefficient varies between 0 and 1 . Zero means that these codes do not co-occur, meanwhile 1 means that the two codes co-occur wherever they are used. However, the database is qualitative, and therefore no p-values are provided [80].

Table 3. Clustering the open answers for "I avoid eating red meat" and "I favor a plant-based diet".

\begin{tabular}{ll}
\hline \multicolumn{1}{c}{ Code } & \multicolumn{1}{c}{ Descriptions } \\
\hline Challenge & Refers to challenges or difficulties, doubts or questions to choose a particular diet. \\
Diversification & Refers to a desire to change or diversify consumption habits or diets. \\
Environment & Refers to concerns about the environment, climate or energy consumption. \\
Ethics & Refers to concerns about animal welfare or refers to personal ethical reasons. \\
Exception & Refers to particular occasions for choosing or avoiding a particular diet. \\
Family & Refers to an impact of a family or household member; either positive or negative. \\
Finances & Refers to financial reasons; either expensiveness or affordability. \\
Health & Refers to health-related concerns or limitations; either positive or negative. \\
Meat replacement & Refers to replacing the red meat with other meat and vegetable substitutes. \\
Origin & Refers to the origin of the food as well to its seasonality. \\
Other & Refers to multiple and diverse reasons for choosing or avoiding a particular diet. \\
Science & Refers to science, research, recommendations or general beliefs. \\
Taste & Refers to personal preferences on the flavor of food. \\
Vegetarian & Refers to already being a vegetarian. \\
Weight & Refers to losing weight or lightening the diet. \\
\hline
\end{tabular}

\section{Results}

\subsection{Descriptive Statistics}

According to the descriptive statistics, locality (mean 3.98) and origin of the food (mean 3.48) were important to Finns (Figure 2). Finns also actively influenced their everyday food choices (3.68), although new information was not considered to be so essential (mean 3.18). Choosing a pro-climate restaurant meal (mean 2.26) scored the lowest along with avoiding red meat (mean 2.48) and favoring plant-based diets (2.92). When environment was related to health (mean 3.29), it scored higher than when solely related to reducing the environmental impacts (mean 2.99).

All these mean averages present sustainability as a multidimensional phenomenon that combines support for the locality, environmental friendliness, health issues and willingness to change behavior. In all of these dimensions, women's eating choices received higher scores than that of men. 


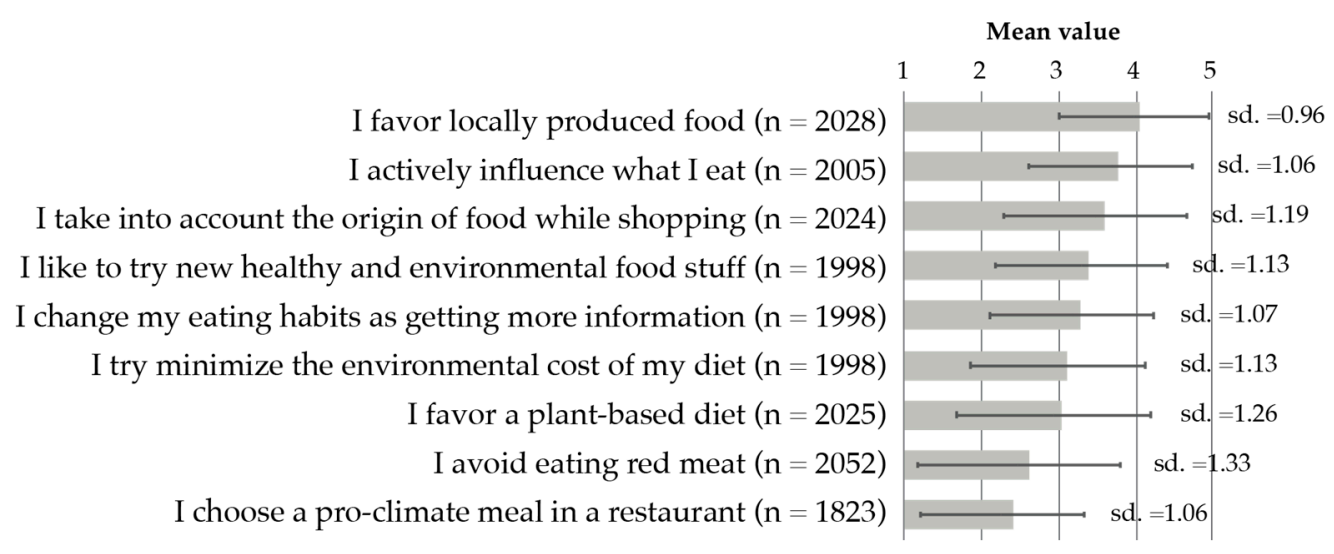

Figure 2. Descriptive statistics of the statements related to food consumption, from the highest to lowest mean (with standard deviation, sd.).

\subsection{Differences between Groups}

In all nine statements, there was a statistically significant difference $(p<0.001)$ among men and women, so that women had systematically higher scores than men. Thus, women prefer more sustainable food than men in Finland.

When taking a closer look at the differences between groups in favoring plant-based diets, we recognized that the differences among different age groups were statistically very significant, $\mathrm{F}(5,1500)=6.89, p<0.001$. Plant-based diets were most common among citizens under 30 years and over 60 years old which means that the behavior was demonstrated in an inverse bell curve. In addition, favoring plant-based diets received high scores until the personal yearly income reached 30,000 euros. Having more money seemed to decrease favoring plant-based diets. Among citizens earning more than 30,000 euros, favoring the plant-based diets decreased significantly, $\mathrm{F}(5,1416)$ $=3.74, p=0.002$. Regarding the place of residence, there was a statistically significant difference, $\mathrm{F}(2,1523)=3.11, p=0.045$, when favoring plant-based diets. We recognized that favoring plant-based diets was highest in the metropolitan area and decreased towards the countryside.

Avoiding red meat varied such that the of 40-49-year-old age group avoided eating red meat the least and, interestingly, the age group of over 70 years old avoided red meat the most. Between the different age groups, there was a statistically very significant difference, $\mathrm{F}(5,1618)=5.66, p<0.001$ Statistically, a significant difference also occurred among the different living areas, $\mathrm{F}(2,1551)=6.11$, $p<0.002$. Citizens in the metropolitan area avoided red meat the most, and citizens in the countryside avoided red meat the least.

Regarding the willingness to try new healthy and environmentally friendly foodstuffs, there were no statistically significant differences among the socio-demographics groups, apart from gender, $\mathrm{F}(1,1986)$ $=111.0, p<0.001$. Women were more willing to try new foodstuffs than men. Nevertheless, willingness to try new foodstuffs decreased with age, but it was not statistically significant $(p<0.061)$.

When considering the willingness to minimize the environmental impacts of the diet, the differences between different age groups were statistically very significant, $\mathrm{F}(5,1606)=7.65, p=0.000$. Finns in the 40-49-year-old group were the least interested in minimizing the environmental impacts of the diet and those over 70 years old were the most interested. Thus, these tendencies were demonstrated by the inverse bell curve. In addition, we detected that personal net income influenced willingness to minimize environmental impacts positively until 40,000 euros. When personal yearly net income is above 40,000 euros, citizens become less interested in the environmental impacts of their diets. The difference was statistically very significant, $\mathrm{F}(5,1391)=3.99, p<0.002$.

Choosing a pro-climate restaurant meal had a great diversity of responses. Statistically, a significant difference $F(5,1423)=5.77, p<0.001$ was found among different age groups. We recognized that the age group under 30 years old had a relatively low interest in choosing pro-climate restaurant meals. 
Also 30-40-year-old Finns were very unlikely to choose a pro-climate restaurant meal. When personal income level increases, choosing a pro-climate restaurant meal is reduced as well. After personal net-income reached the level 30,000 euros, the decrease was steep. The difference between different income groups was a statistically significant, $\mathrm{F}(5,1287)=2.65, p<0.03$.

When comparing the activeness or passiveness to influence diet, there was a statistically significant difference between the metropolitan area and other living areas, $\mathrm{F}(2,2002)=3.11, p<0.045$. In the metropolitan area, the activity of people was higher than people living in other areas. Regarding the age groups, we recognized that 30-39-years-old Finns were the most active in influencing their diets. Respectively, 40-49-years-old Finns were the most passive in influencing their diet. Between the different age groups, there was a statistically significant difference, $\mathrm{F}(4,1619)=2.76, p<0.02$.

\subsection{Reasoning of Food Choices}

Health-related issues were the most common reasons either to avoid red meat (25.5\%) or to favor plant-based diets (36.8\%) (Figure 3) When avoiding red meat, answers included multiple concerns such as a fear of cancer, increased cholesterol or abdominal problems-the respondents were mainly reducing their red meat consumption because of the feared negative impacts. Respectively, the open answers emphasized the personal well-being and a desire to live healthier as the primary reason when favoring plant-based diets-the respondents were mainly increasing their vegetable consumption because of the hoped positive impacts.

Next to health-related issues, were concerns about the state of the environment, climate change and the exploitation of environmental resources for avoiding red meat $(16.2 \%)$ or for favoring plant-based diets (12.4\%). The content of these open answers was similar for both statements, but the respondents did not fully specify whether the concerns were related to Finland or to the global situation.

Personal preferences or taste were mentioned as the fourth most common reason (10.2\%) to avoid red meat and as the third most common reason (11.9\%) to favor plant-based diets. Again, the reasons to avoid red meat were often seen negatively such as disliking the taste of meat, and respectively, the plant-based diets often received embraces for the flavors of vegetables. Third most commonly $(12.5 \%)$ respondents avoided or reduced their red meat consumption by eating white meat or vegetables, indicating that there is already an increasing movement towards favoring plant-based diets.

After the third or fourth most common reasons, there was more dispersion between the reasons to avoid red meat or to favor plant-based diets. Ethics, such as the concern about the animal welfare or welfare, was relatively high for the respondents either to avoid red meat $(9.7 \%$, the fifth most common reason) or to favor plant-based diets (5.2\%, the sixth most common reason). In the open answers, some of the respondents felt very strongly about this, and the diets were considered as an important way of living or as a personal statement. Interestingly, the desire to lighten the diets or lose weight, was the fourth most common (10.6\%) reason to favor plant-based diets but the tenth most common $(1.9 \%)$ reason to avoid red meat. This linked closely to the health-related issues, especially for favoring plant-based diets, where the aim was to live healthier.

The respondents did not have any significant challenges or difficulties, doubts or questions either to avoid red meat $(1.9 \%$, the 11 th most common) or to favor plant-based diets $(1.6 \%$, the 13 th most common). In addition, the Finnish consumers seemed to be independent decision-makers, since family was mentioned only as the 14 th most common reason (1.4\%) to avoid red meat or as the ninth most common reason $(2.2 \%)$ to favor plant-based diets.

Some of the answers (Figure 3) had multiple reasons whether to avoid red meat or to favor plant-based diets. When looking at the main reasons to avoid red meat (Figure 4), the highest connections were between the environment and ethics (c-coefficient 0.17 ), and between the environment and health (c-coefficient 0.14). There was also a correlation between health and ethics (c-coefficient 0.09), and between the origin of the food and particular occasions (c-coefficient 0.09 ). The particular occasions were often related to holidays meals, such as Christmas or Easter, or the respondents described that 
they consumed red meat only during exceptional occasions such as dinners in restaurants or meals hosted by someone else.

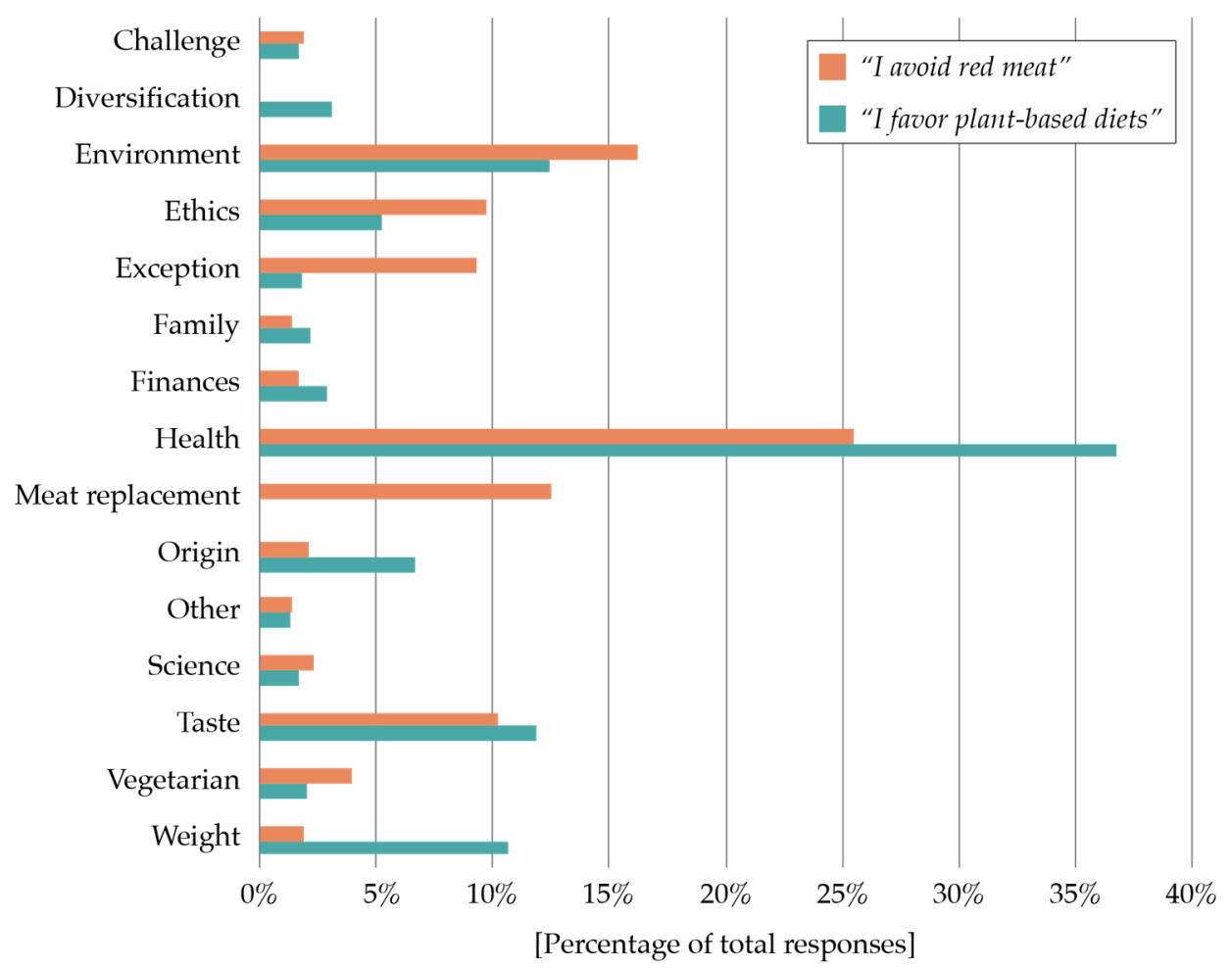

Figure 3. Different reasons for avoiding eating red meat (orange color) or favoring plant-based diets (green color) expressed as a percentage of total responses, if the respondents evaluated that they agreed (Likert scale 4 ) or totally agreed (Likert scale 5) with the given statement.

When looking at the connections between the main reasons to favor plant-based diets (Figure 4), health-related reasons connected with environmental concerns (c-coefficient 0.13) and with weight control (c-coefficient 0.10). Respectively, the environment had a high connection with ethics (c-coefficient 0.15 ) which was often explained by a common concern about the environment and animal welfare.

The challenges and difficulties for avoiding red meat or favoring plant-based diets, presented an interesting study area that reflected also respondents' attitudes. Women sometimes specified that they were reducing their red meat consumption but their spouses were not. Nevertheless, this was not explained as a challenge-rather only as a remark, and therefore there is not a connection between family members and challenges when avoiding red meat. This was opposite in the favoring plant-based diets, where the connection between family members and challenges was the highest (c-coefficient 0.17). Again, sometimes women were answering that they would increase their vegetable consumption but found it difficult because the resistant in the family. Nevertheless, it is good to acknowledge that the overall the family influence was not ranked high (Figure 3), and therefore the connection (Figure 4) seems higher than it might actually be. 


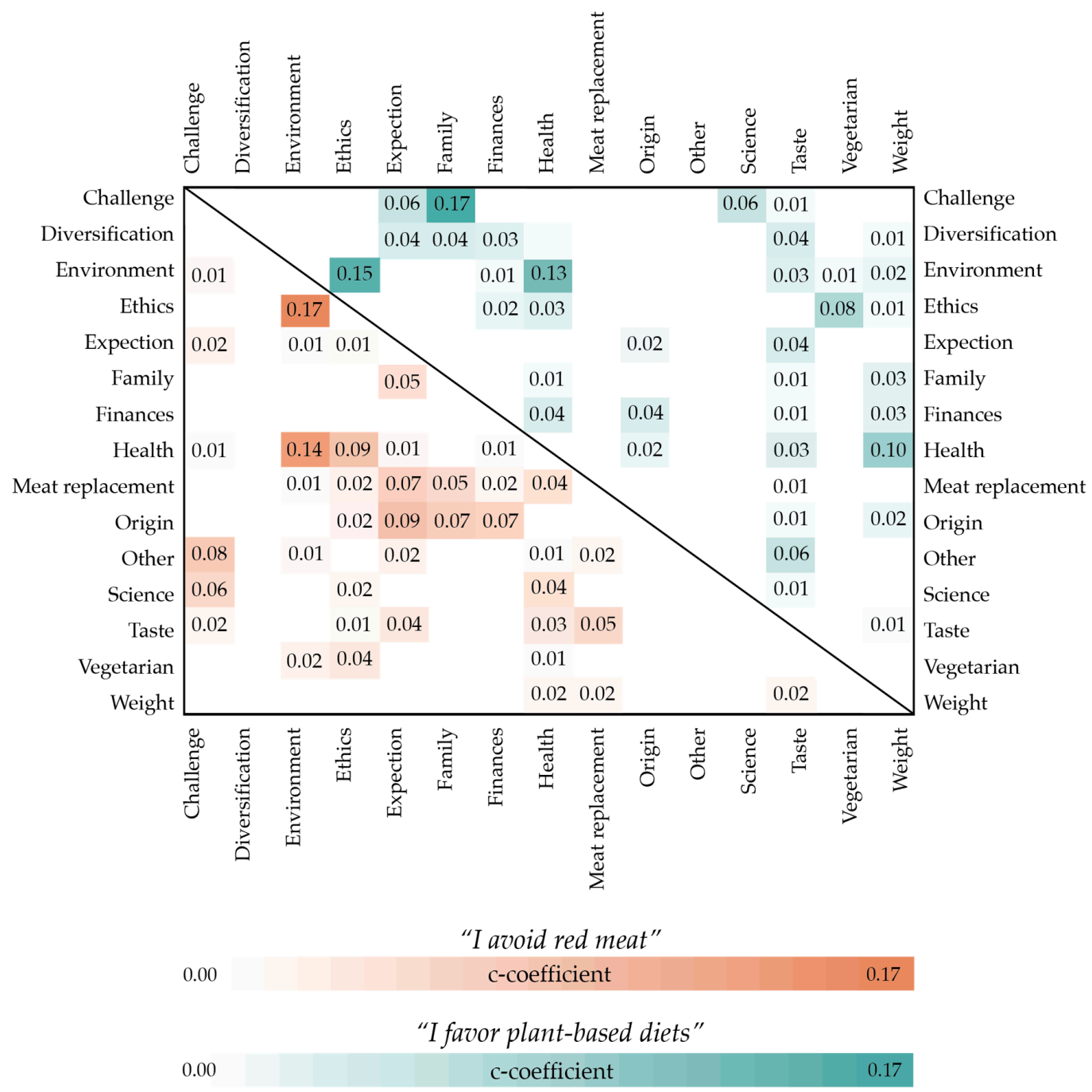

Figure 4. Interconnections between the clustering for favoring plant-based diets based on the c-coefficient values (meaning that the multiple reasons were given for the same answer).

\section{Discussion and Concluding Remarks}

\subsection{Progressive Urban Women and Wealthy Middle-Aged Men}

Similar to previous studies [53-55], our results also indicate differences between men and women. In general, women's lifestyles are more ecologically and socially sustainable than men's in western countries $[15,81,82]$. We also discovered that Finnish women were more environmentally aware and more willing to try new environmental and healthy foodstuffs. As a general assumption, women also are often more responsible for households and cooking, and our analysis presented that there is a connection between the challenge of favoring plant-based diets and being influenced by family members (Figure 4). Similar findings were discovered in Scotland, where some women stated that they found reduction of meat consumption problematical because of their husbands or partners [19].

We discovered that the age group over 70 years old avoided red meat the most, which is also supported by a decline in appetite with ageing found by Verbeke et al. [62]. In Finland, like in other Nordic countries, the consumption of meat has increased significantly over the last decades $[11,21]$ and meat is not anymore considered as a luxury product like it used to be centuries ago [8]. It might simply be that the older generation is not used to eating meat as it is consumed averagely in Finland today for several reasons such as the cost of the meat, poor dentition and digestive issues. Overall, the older generation's attitudes towards meat might be more conservative than the younger generation. 
Respectively, the age groups under 30 and over 60 years also favored plant-based diets the most. Finnish younger generation is more exposed to vegetarian options because of the changes in the food culture and international trade [83], that has diversified the traditional diets with imported foodstuff. Previous studies have presented that offering more meat-free meals would increase their selection $[9,53]$. This might also be explained by the geographical differences among metropolitan areas, other cities and the countryside in Finland: there are more vegetarians options, including vegetarian restaurants, in the cities than in the countryside. This was opposite to the global assumption that the animal protein consumption increases in the cities [50], but applies to a hypothesis about the saturation levels in meat consumption, where Henchion et al. [84] explain that the external reasons such as climate change, obesity, technology advancements and changes in lifestyles might be changing the policy initiatives as well consumer behavior towards reduced or levelled meat consumption.

Our results also displayed that the taste of food was important for Finnish people and was ranked relatively high, whether when avoiding red meat or favoring plant-based diets. This emphasizes the power of personal choices and motivation that Finnish people have over their food consumption. On average, Finnish citizens spend around $10 \%$ of the expenses for food (reference on the year 2016) - for low-income earners that is the second highest expenses group and for high-income earners that is only the fifth highest expenses group [85]. It is still important to acknowledge that this presents only the average, and there is an increasing number of people who are dependent on food aid $[86,87]$. Thus, people do not always have the option to choose their preferred diets but are tied into the existing conditions and surrounding restrictions. However, it seems that people who consume meat more frequently and have a positive attitude towards meat consumption, are also less willing to reduce their meat consumption [9].

In Finland, the average annual net-income is around 29,000 euros (Table 1). Our results present that when personal net-income was higher than 30,000 euros, favoring plant-based meals decreased significantly. On average, men earn more in Finland than women, and are more active in the working life [88]. Thus, it can be speculated that on average the people groups earning more than the average income, are far in their career path and therefore also middle-age or older. This is supported by the data showing, that the age group of 40-49-year-old favored red meat the most.

Based on these findings, we can reason that the women living in the metropolitan areas are more progressive and willing to change their diets towards more sustainable options. An opposite conclusion can be assumed: currently it is less likely that middle-aged men, with higher incomes, will change their diets. Nevertheless, based on the previous results and our findings regarding age and global trade, we can assume that the entire food culture is in a transition, and that future generations will dictate its direction.

\subsection{The Potential Towards More Sustainable Diets in Finland}

Based on previous research [14], it seems that Finnish people have enough information about food-related issues. Nevertheless, science or official recommendations scored averagely when people explained their specific reasons to avoid red meat or favor vegetables. Macdiarmid et al. [19] discovered that the increasing information about diets does not always guide people, and this seems to be the case in our study as well.

Respectively, open answers related to personal health and well-being scored the highest in both statements (Figure 3). It seems that knowledge is more related to a personal well-being rather than the environmental impacts of food production. Losing weight was emphasized as one of the main reasons to favor plant-based diets. As an example, in the statements (Figure 2) "I like to try new healthy and environmental foodstuff" scored higher than "I try to minimize the environmental cost of my diet", which implies that the environmental impacts alone do not seem too important for Finnish people. Our hypothesis is therefore that health benefits, such as lighter meals, weight control and diversifying diets, would be effective ways to decrease red meat consumption and increase plant-based meals in the Finnish context. 
Previous studies presented that the environmental impacts, when even recognized, are more known and associated with packaging, food waste and transportation, rather than food consumption $[19,50]$. Furthermore, the impacts of global food crises might also seem very distant to Finnish citizens, although Finland benefits significantly from global trade $[83,89,90]$. Thus, it might be that Finnish citizens are simply not aware of their environmental impact in local or global contexts.

Nevertheless, it is good to acknowledge the local context-Finland has vast natural resources for agricultural production compared to many other countries [91,92]. In addition, a majority of Finnish people live in urban settings [93], and thus primary production might feel alien to the majority of citizens. Finnish primary production is going through structural changes, like in the rest of Europe, and farm sizes are increasing while the number of farms is decreasing [94]. In the midst of these changes, it is good to acknowledge that locality could bring economic benefits to certain production areas. Max-Neef [70] argued that the economic sustainability creates local employment and business opportunities when money stays within the specific areas and countries. Our results also emphasized the importance of local food to Finnish people, and preference for local food was considered high (Figure 2) [15]. However, this is not often reflected in the real purchasing situation at grocery stores [14], and people tend to make to their buying decisions based on something else, such as price. We can therefore assume that the appreciation of domestic food is important to Finns, yet is not reflected in everyday life.

Consequently, we state that there is a realistic potential to mainstream sustainable diets, but it relies on people's knowledge and personal motivations to change their diets. As stated, the Finnish citizen does not follow the typical consumer model regarding personal income-rather, consumption habits are shaped by personal preferences.

\subsection{Limitations of the Study and Future Research}

We applied variance analysis as a quantitative research method. ANOVA is a fairly robust research method in terms of error rate [78]. However, violation of homogeneity of variance was our challenge. All the inspected groups were no equal-sized. In order to take care of this challenge, we reported Brown-Forsythe F-ratios. By doing so, we reduced the impact of large sample sizes with large variance. This was important because we know that $F$-ratio tends to be conservative in a situation where groups with larger sample sizes have large variances than the groups with smaller sample sizes [79].

Even though our analysis provided valuable new and current information about Finnish citizens' consumption habits, the phrasing in the questionnaire may have influenced respondents' presumptions and answers. The respondents were asked to estimate their behavior regarding how they "avoid red meat" or "favor plant-based diets". This could have already directed what generally is considered to be good or bad choices [14]. Therefore, the respondents might have understated or exaggerated their behavior or consumption habits based on the phrasing in the questionnaire.

It is also important to acknowledge that not all the participants $(n=2052)$ explained their statements by open answers, and therefore the qualitative analysis supplemented only partly to the original sample. The qualitative analysis was also done in Finnish and translated into English, and therefore some of the deeper cultural content was needed in the interpretations that might have also impacted on the clustering (Table 3).

The neglected open answers indicated that many of the respondents were already reducing their red meat consumption or increasing their vegetable consumption. This provided information supporting the idea that a transition towards more sustainable diets is possible, and is actually happening, but it did not indicate the state of the current consumption level. As studied by Macdiarmid et al. [19], if people feel that they are already doing something different compared to their ordinary consumption habits, they do not have any further need or desire to change their diets. More specified questions and answers regarding the reduction or increased quantities (e.g., $\mathrm{g} \mathrm{cap}^{-1}$ week $^{-1}$ ) of meat consumption would help to understand the current state. In addition, it is also important to consider what is meant by meat or by red meat. Globally, consumption of meat has increased but a considerable 
amount of increased meat consumption is consumption of poultry [50]. Our research focused only on red meat-consumption of poultry was not within the scope of this study.

This research focused only on citizens and their personal preferences, but future research should also focus on the politicians or municipal officials responsible for public procurements [95]. Vinnari and Tapio [24] suggested that the taxing products at a higher rate is not sufficient as different groups would need to be persuaded in different ways regarding the benefits of altering their diets and beliefs. Finnish legislation guarantees pupils and students the right to free meals during school days from pre-primary and basic education until the completion of upper secondary education [96]. Therefore, we suggest that there is a great chance to direct people's consumption habits toward more sustainable diets through public procurements.

\section{Conclusions}

We found that choosing sustainable diets is a multiform phenomenon where health and environmental reasons were mentioned as a first priority, but other reasons such as taste, ethics or losing weight were emphasized as well. In addition, the different socio-demographic indicators, such as gender and age, impacted clearly personal choices. Finnish society is relatively wealthy by global standards, and citizens are able to choose their diets based on personal preferences. Finnish people do not perhaps see the connection between their food consumption and nature depletion, while the connection between diets and well-being is more subjective and known to Finns. Emphasizing health impacts and weight control is highly valued among Finns, and directly influences diet choices such as whether to avoid red meat or favor plant-based diets. Environmental awareness also appears in the background but it is not perhaps strong enough to be the leading driver to change diets to be more sustainable. Thus, our conclusion is that the potential transition towards more sustainable diets among Finns is the most powerful when people can combine the selfish, hedonistic factors (e.g., health, weight management) and altruistic factors (e.g., ecological benefits) in their everyday diets. The key to mainstream sustainable diets lies in the co-benefits.

Author Contributions: Conceptualization, Methodology, Writing; E.L. and A.O.S., Qualitative analysis: E.L., Quantitative analysis: A.O.S., Visualization: E.L. and Supervision: A.O.S.

Acknowledgments: Elina Lehikoinen and Arto O. Salonen acknowledge funding from the Strategic Research Council (SRC) funded 'From Failand to Winland' project. The authors would like to thank Matti Kummu (Aalto University) for his valuable comments on the manuscript and Amy Fallon (Aalto University) for her help with the language.

Conflicts of Interest: The authors declare no conflicts of interest.

\section{References}

1. Gerland, P.; Raftery, A.E.; Ševčíková, H.; Li, N.; Gu, D.; Spoorenberg, T.; Alkema, L.; Fosdick, B.K.; Chunn, J.; Lalic, N.; et al. World population stabilization unlikely this century. Science 2014, 346, 234-237. [CrossRef] [PubMed]

2. United Nations. World Population Prospects: The 2017 Revision, Key Findings and Advance Tables; ESA/P/WP/248; United Nations Department of Economic and Social Affairs/Population Division: New York, NY, USA, 2017.

3. Kummu, M.; Fader, M.; Gerten, D.; Guillaume, J.H.; Jalava, M.; Jägermeyr, J.; Pfister, S.; Porkka, M.; Siebert, S.; Varis, O. Bringing it all together: Linking measures to secure nations' food supply. Curr. Opin. Environ. Sustain. 2017, 29, 98-117. [CrossRef]

4. Springmann, M.; Clark, M.; Mason-D'Croz, D.; Wiebe, K.; Bodirsky, B.L.; Lassaletta, L.; de Vries, W.; Vermeulen, S.J.; Herrero, M.; Carlson, K.M.; et al. Options for keeping the food system within environmental limits. Nature 2018, 562, 519-525. [CrossRef] [PubMed]

5. Mäkelä, J. Syömisen rakenne ja kulttuurinen vaihtelu; Kuluttajatutkimuskeskus: Helsinki, Finland, 2002.

6. Grunert, K.G. Future trends and consumer lifestyles with regard to meat consumption. Meat Sci. 2006, 74, 149-160. [CrossRef] [PubMed] 
7. Wahlqvist, M.L.; Lee, M.-S. Regional Food Culture and Development. Asia Pac. J. Clin. Nutr. 2007, 16, 2-7. [PubMed]

8. Fogelholm, M.; Hopia, A.; Katajajuuri, J.-M.; Kulanko, H.; Lehtonen, H.; Luukkonen, O.; Mäkelä, J.; Niva, M.; Ovaskainen, M.-L.; Pohjolainen, P.; et al. Vähemmän lihaa. Kohti kestävää ruokakulttuuria; Mattila, H., Ed.; Gaudeamus: Helsinki, Finland, 2016; ISBN 978-952-495-388-7.

9. Hartmann, C.; Siegrist, M. Consumer perception and behaviour regarding sustainable protein consumption: A systematic review. Trends Food Sci. Technol. 2017, 61, 11-25. [CrossRef]

10. Sabaté, J.; Soret, S. Sustainability of plant-based diets: Back to the future. Am. J. Clin. Nutr. 2014, 100, 476S-482S. [CrossRef] [PubMed]

11. Mithril, C.; Dragsted, L.O.; Meyer, C.; Blauert, E.; Holt, M.K.; Astrup, A. Guidelines for the New Nordic Diet. Public Health Nutr. 2012, 15, 1941-1947. [CrossRef] [PubMed]

12. Vanhonacker, F.; Van Loo, E.J.; Gellynck, X.; Verbeke, W. Flemish consumer attitudes towards more sustainable food choices. Appetite 2013, 62, 7-16. [CrossRef] [PubMed]

13. Vermeir, I.; Verbeke, W. Sustainable food consumption among young adults in Belgium: Theory of planned behaviour and the role of confidence and values. Ecol. Econ. 2008, 64, 542-553. [CrossRef]

14. Jarvela, K.; Makela, J.; Piiroinen, S. Consumers' everyday food choice strategies in Finland. Int. J. Consum. Stud. 2006, 30, 309-317. [CrossRef]

15. Salonen, A.O.; Fredriksson, L.; Järvinen, S.; Korteniemi, P.; Danielsson, J. Sustainable Consumption in Finland-The Phenomenon, Consumer Profiles, and Future Scenarios. Int. J. Mark. Stud. 2014, 6, 59-82. [CrossRef]

16. Cordts, A.; Nitzko, S.; Spiller, A. Consumer Response to Negative Information on Meat Consumption in Germany. Int. Food Agribus. Manag. Rev. 2014, 17, 83-106.

17. De Boer, J.; Schösler, H.; Aiking, H. "Meatless days" or "less but better"? Exploring strategies to adapt Western meat consumption to health and sustainability challenges. Appetite 2014, 76, 120-128. [CrossRef] [PubMed]

18. Schösler, H.; de Boer, J.; Boersema, J.J.; Aiking, H. Meat and masculinity among young Chinese, Turkish and Dutch adults in the Netherlands. Appetite 2015, 89, 152-159. [CrossRef] [PubMed]

19. Macdiarmid, J.I.; Douglas, F.; Campbell, J. Eating like there's no tomorrow: Public awareness of the environmental impact of food and reluctance to eat less meat as part of a sustainable diet. Appetite 2016, 96, 487-493. [CrossRef] [PubMed]

20. Campbell-Arvai, V. Food-related environmental beliefs and behaviours among university undergraduates: A mixed-methods study. Int. J. Sustain. High. Educ. 2015, 16, 279-295. [CrossRef]

21. Åby, B.A.; Kantanen, J.; Aass, L.; Meuwissen, T. Current status of livestock production in the Nordic countries and future challenges with a changing climate and human population growth. Acta Agric. Scand. Sect. A Anim. Sci. 2014, 64, 73-97. [CrossRef]

22. Gerber, P.J.; Steinfeld, H.; Henderson, B.; Mottet, A.; Opio, C.; Dijkman, J.; Falcucci, A.; Tempio, G. Tackling Climate Change through Livestock: A Global Assessment of Emissions and Mitigation Opportunities; Gerber, P.J., Steinfeld, H., Mottet, A., Opio, C., Dijkman, J., Falcucci, A., Tempio, G., Eds.; Food and Agriculture Organization of the United Nations: Rome, Italy, 2013; ISBN 978-92-5-107920-1.

23. FAOSTAT Food Balance Sheets. Available online: http://www.fao.org/faostat/en/\#data/FBS (accessed on 24 September 2018).

24. Vinnari, M.; Tapio, P. Future images of meat consumption in 2030. Futures 2009, 41, 269-278. [CrossRef]

25. Valsta, L.; Kaartinen, N.; Tapanainen, H.; Männistö, S.; Sääksjärvi, K. Ravitsemus Suomessa-FinRavinto 2017-tutkimus [Nutrition in Finland-The National FinDiet 2017 Survey]; Institute for Health and Welfare (THL): Helsinki, Finland, 2018; p. 239.

26. Fogelholm, M.; Hakala, P.; Kara, R.; Kiuru, S.; Kurppa, S.; Kuusipalo, H.; Laitinen, J.; Marniemi, A.; Misikangas, M.; Roo, E.; et al. Suomalaiset ravitsemussuositukset; Valtion ravitsemusneuvottelukunta: Tampere, Finland, 2014; p. 60.

27. Burlingame, B.; Dernini, S. Sustainable Diets and Biodiversity—Directions and Solutions for Policy Research and Action. In Proceedings of the International Scientific Symposium Biodiversity and Sustainable Diets United Against Hunger, Rome, Italy, 3-5 November 2010; Burlingame, B., Dernini, S., Eds.; FAO: Rome, Italy, 2012; ISBN 978-92-5-107288-2. 
28. Nordic Council of Ministers. Nordic Nutrition Recommendations 2012. Integrating Nutrition and Physical Activity, 5th ed.; Nordic Council of Ministers: Copenhagen, Denmark, 2014; p. 629.

29. Salonen, A.O.; Helne, T.T. Vegetarian Diets: A Way towards a Sustainable Society. J. Sustain. Dev. $2012,5$. [CrossRef]

30. De Bakker, E.; Dagevos, H. Reducing Meat Consumption in Today's Consumer Society: Questioning the Citizen-Consumer Gap. J. Agric. Environ. Ethics 2012, 25, 877-894. [CrossRef]

31. Jalava, M.; Kummu, M.; Porkka, M.; Siebert, S.; Varis, O. Diet change-A solution to reduce water use? Environ. Res. Lett. 2014, 9, 074016. [CrossRef]

32. Hoek, A.C.; Luning, P.A.; Weijzen, P.; Engels, W.; Kok, F.J.; de Graaf, C. Replacement of meat by meat substitutes. A survey on person- and product-related factors in consumer acceptance. Appetite 2011, 56, 662-673. [CrossRef] [PubMed]

33. Ruby, M.B.; Heine, S.J. Meat, morals, and masculinity. Appetite 2011, 56, 447-450. [CrossRef] [PubMed]

34. Schösler, H.; de Boer, J.; Boersema, J.J. Can we cut out the meat of the dish? Constructing consumer-oriented pathways towards meat substitution. Appetite 2012, 58, 39-47. [CrossRef] [PubMed]

35. Tobler, C.; Visschers, V.H.M.; Siegrist, M. Eating green. Consumers' willingness to adopt ecological food consumption behaviors. Appetite 2011, 57, 674-682. [CrossRef] [PubMed]

36. Ruby, M.B. Vegetarianism. A blossoming field of study. Appetite 2012, 58, 141-150. [CrossRef] [PubMed]

37. Neumann, C.; Harris, D.M.; Rogers, L.M. Contribution of animal source foods in improving diet quality and function in children in the developing world. Nutr. Res. 2002, 22, 193-220. [CrossRef]

38. McAfee, A.J.; McSorley, E.M.; Cuskelly, G.J.; Moss, B.W.; Wallace, J.M.W.; Bonham, M.P.; Fearon, A.M. Red meat consumption: An overview of the risks and benefits. Meat Sci. 2010, 84, 1-13. [CrossRef] [PubMed]

39. Pan, A.; Sun, Q.; Bernstein, A.M.; Schulze, M.B.; Manson, J.E.; Stampfer, M.J.; Willett, W.C.; Hu, F.B. Red Meat Consumption and Mortality: Results From 2 Prospective Cohort Studies. Arch. Intern. Med. 2012, 172, 555. [PubMed]

40. Sinha, R.; Cross, A.J.; Graubard, B.I.; Leitzmann, M.F.; Schatzkin, A. Meat Intake and Mortality: A Prospective Study of Over Half a Million People. Arch. Intern. Med. 2009, 169, 562. [CrossRef] [PubMed]

41. WHO. Diet, Nutrition, and the Prevention of Chronic Diseases: Report of a WHO-FAO Expert Consultation; WHO technical report series; World Health Organization: Geneva, Switzerland, 2003; ISBN 978-92-4-120916-8.

42. Bouvard, V.; Loomis, D.; Guyton, K.; Grosse, Y.; El Ghissassi, F.; Benbrahim-Tallaa, L.; Guha, N.; Mattock, H.; Straif, K. Carcinogenicity of consumption of red and processed meat. Lancet Oncol. 2015, 16, 1599-1600. [CrossRef]

43. Pan, A.; Sun, Q.; Bernstein, A.M.; Schulze, M.B.; Manson, J.E.; Willett, W.C.; Hu, F.B. Red meat consumption and risk of type 2 diabetes: 3 cohorts of US adults and an updated meta-analysis. Am. J. Clin. Nutr. 2011, 94, 1088-1096. [CrossRef] [PubMed]

44. WHO. A Healthy Diet Sustainably Produced, Information Sheet; World Health Organization: Geneva, Switzerland, 2018; p. 7.

45. WCRF. Recommendations and Public Health and Policy Implications; Continuous Update Project Expert Report 2018; World Cancer Research Fund/American Institute for Cancer Research: London, UK, 2018; p. 92.

46. Hoekstra, A.Y. The hidden water resource use behind meat and dairy. Anim. Front. 2012, 2, 3-8. [CrossRef]

47. Steinfeld, H.; Gerber, P.; Wassenaar, T.D.; Castel, V.; Rosales, M.; de Haan, C. Livestock's Long Shadow: Environmental Issues and Options; Food and Agriculture Organization of the United Nations: Rome, Italy, 2006; ISBN 978-92-5-105571-7.

48. Kummu, M.; Varis, O. The world by latitudes: A global analysis of human population, development level and environment across the north-south axis over the past half century. Appl. Geogr. 2011, 31, 495-507. [CrossRef]

49. Lehikoinen, E.; Parviainen, T.; Helenius, J.; Jalava, M.; Salonen, A.; Kummu, M. Cattle Production for Exports in Water-Abundant Areas: The Case of Finland. Sustainability 2019, 11, 1075. [CrossRef]

50. Kearney, J. Food consumption trends and drivers. Philos. Trans. R. Soc. B Biol. Sci. 2010, 365, $2793-2807$. [CrossRef] [PubMed]

51. Smil, V. Worldwide transformation of diets, burdens of meat production and opportunities for novel food proteins. Enzym. Microb. Technol. 2002, 30, 305-311. [CrossRef]

52. Tukker, A.; Jansen, B. Environmental Impacts of Products: A Detailed Review of Studies. J. Ind. Ecol. 2006, 10, 159-182. [CrossRef] 
53. Campbell-Arvai, V.; Arvai, J.; Kalof, L. Motivating Sustainable Food Choices: The Role of Nudges, Value Orientation, and Information Provision. Environ. Behav. 2014, 46, 453-475. [CrossRef]

54. Stern, P.C.; Dietz, T.; Kalof, L. Value Orientations, Gender, and Environmental Concern. Environ. Behav. 1993, 25, 322-348. [CrossRef]

55. Zelezny, L.C.; Chua, P.-P.; Aldrich, C. New Ways of Thinking about Environmentalism: Elaborating on Gender Differences in Environmentalism. J. Soc. Issues 2000, 56, 443-457. [CrossRef]

56. De Boer, J.; Aiking, H. On the merits of plant-based proteins for global food security: Marrying macro and micro perspectives. Ecol. Econ. 2011, 70, 1259-1265. [CrossRef]

57. Siegrist, M.; Visschers, V.H.M.; Hartmann, C. Factors influencing changes in sustainability perception of various food behaviors: Results of a longitudinal study. Food Qual. Prefer. 2015, 46, 33-39. [CrossRef]

58. Salonen, A.; Hakari, S. Early Childhood Educators and Sustainability: Sustainable Living and Its Materialising in Everyday Life. Utbilding Demokr. 2019, 27, 81-102.

59. Salonen, A.O.; Tast, S. Finnish Early Childhood Educators and Sustainable Development. J. Sustain. Dev. 2013, 6, 70-85. [CrossRef]

60. Becker, T.; Benner, E.; Glitsch, K. Summary Report on Consumer Behaviour Towards Meat in Germany, Ireland, Italy, Spain, Sweden and the United Kingdom: Results of a Consumer Survey; Department of Agricultural Policy and Agricultural Economics, University of Hohenheim, Göttingen: Stuttgart, Germany, 1998.

61. Glitsch, K. Verhalten europäischer Konsumenten und Konsumentinnen gegenüber Fleisch: Eine theoretische und empirische Analyse. Ph.D. Thesis, University of Hohenheim, Göttingen, Stuttgart, Germany, 1998.

62. Verbeke, W.; Ward, R.W.; Viaene, J. Probit analysis of fresh meat consumption in Belgium: Exploring BSE and television communication impact. Agribusiness 2000, 16, 215-234. [CrossRef]

63. Tilman, D.; Clark, M. Global diets link environmental sustainability and human health. Nature 2014, 515, 518-522. [CrossRef] [PubMed]

64. Popkin, B.M. Urbanization, Lifestyle Changes and the Nutrition Transition. World Dev. 1999, 27, $1905-1916$. [CrossRef]

65. Diekmann, A.; Preisendörfer, P. Environmental behavior: Discrepancies between aspirations and reality. Ration. Soc. 1998, 10, 79-102. [CrossRef]

66. Stern, P.C. New Environmental Theories: Toward a Coherent Theory of Environmentally Significant Behavior. J. Soc. Issues 2000, 56, 407-424. [CrossRef]

67. Salonen, A.O.; Danielsson, J.; Fredriksson, L.; Järvinen, S.; Korteniemi, P.; Soininen, H.; Toivola, T. Seuraamustietoinen kuluttaminen arvoteoreettisessa tarkastelussa. Kulutustustkimus. Nyt 2015, 9, 29.

68. Holm, L.; Palojoki, P. Consumers and Society in Dialogue. In Proceedings of the IFHE European Conference, Kyoto, Japan, 1-7 August 2004; Swedish Committee for Home Economics: Stockholm, Sweden, 2004; pp. 70-75.

69. Regan, Á.; McConnon, Á.; Kuttschreuter, M.; Rutsaert, P.; Shan, L.; Pieniak, Z.; Barnett, J.; Verbeke, W.; Wall, P. The impact of communicating conflicting risk and benefit messages: An experimental study on red meat information. Food Qual. Prefer. 2014, 38, 107-114. [CrossRef]

70. Max-Neef, M. The World on a Collision Course and the Need for a New Economy: Contribution to the 2009 Royal Colloquium. AMBIO 2010, 39, 200-210. [CrossRef] [PubMed]

71. Verain, M.C.D.; Dagevos, H.; Antonides, G. Sustainable food consumption. Product choice or curtailment? Appetite 2015, 91, 375-384. [CrossRef] [PubMed]

72. Statistics Finland Vital Statistics and Population by Area, 1990-2017. Available online: http:/ / pxnet2.stat.fi/PXWeb/pxweb/en/StatFin/StatFin_vvrm__muutl/statfin_muutl_pxt_11ae. px/?rxid=1cbaa645-1c9a-49bb-9bda-b7232971b1f7 (accessed on 22 January 2019).

73. Statistics Finland Population by Sex in 1750 to 2017. Available online: http://pxnet2.stat.fi/PXWeb/ pxweb/en/StatFin/StatFin_vrm_vaerak/statfin_vaerak_pxt_003.px/?rxid=24e30cdb-60c4-483e-9c265823eda6b66e (accessed on 22 January 2019).

74. Statistics Finland Preliminary Population by Quarter and Area in 2010 to 2018 . Available online: http:/ / pxnet2.stat.fi /PXWeb/pxweb/en/StatFin/StatFin_vrm_vamuu/statfin_vamuu_pxt_003. px/?rxid=6a55df11-0386-431e-a89f-a631245403e8 (accessed on 22 January 2019).

75. Statistics Finland Number of Income Recipients by Income-Class. 2017. Available online: http:/ / pxnet2.stat.fi/PXWeb/pxweb/en/StatFin/StatFin_tul_tvt/statfin_tvt_pxt_11g6.px/?rxid= 24e30cdb-60c4-483e-9c26-5823eda6b66e (accessed on 22 January 2019). 
76. Statistics Finland Population according to Urban-Rural Classification by Age and Sex in 2000 to 2017. Available online: http:/ / pxnet2.stat.fi/PXWeb/pxweb/en/StatFin/StatFin_vrm_vaerak/statfin_vaerak_ pxt_023.px/?rxid=24e30cdb-60c4-483e-9c26-5823eda6b66e (accessed on 31 January 2019).

77. Statistics Finland Income and Consumption. Available online: https://www.tilastokeskus.fi/tup/suoluk/ suoluk_tulot_en.html (accessed on 14 November 2018).

78. Tabachnick, B.; Fidell, L. Using Multivariate Statistics, 5th ed.; Pearson International Edition: London, UK, 2007.

79. Field, A.P. Discovering Statistics Using SPSS: And Sex, Drugs and Rock " $n$ " Roll, 3rd ed.; SAGE Publications: Los Angeles, CA, USA, 2009; ISBN 978-1-84787-906-6.

80. Friese, S. Qualitative Data Analysis with ATLAS.ti, 2nd ed.; SAGE: Los Angeles, CA, USA, 2014; ISBN 978-1-4462-8203-8.

81. Johnsson-Latham, G. A Study on Gender Equality as a Prerequisite for Sustainable Development; Report to the Environment Advisory Council, Sweden 2007:2; The Environment Advisory Council, Ministry of the Environment: Stockholm, Sweden, 2007; p. 90.

82. Koskela, M. Ympäristöasenteet ja -Toiminta Kuntaorganisaatioissa. Espoon, Helsingin, Jyväskylän, Oulun, Tampereen, Turun ja Vantaan Kaupungit; Tulevaisuuden tutkimuskeskus ja Turun kauppakorkeakoulu: Turku, Finland, 2008.

83. Sandström, V.; Saikku, L.; Antikainen, R.; Sokka, L.; Kauppi, P. Changing impact of import and export on agricultural land use: The case of Finland 1961-2007. Agric. Ecosyst. Environ. 2014, 188, 163-168. [CrossRef]

84. Henchion, M.; McCarthy, M.; Resconi, V.C.; Troy, D. Meat consumption: Trends and quality matters. Meat Science 2014, 98, 561-568. [CrossRef] [PubMed]

85. Statistics Finland. Kotitalouksien Kulutus 2016 (Households' Consumption 2016); Statistics Finland: Helsinki, Finland, 2016; p. 11.

86. Lintula, L. Köyhyyskulttuuria hyvinvointivaltiossa? Tutkimus toimeentulotukiasiakkaista ruokajonossa. Master's Thesis, Sosiaalitieteiden laitos, sosiaalipolitiikka, Turun yliopisto, Turku, Finland, 2018.

87. Silvasti, T. Ruoka-avun vakiinnuttaminen Suomessa. Tarpeen ja oikeutuksen jäljillä. Janus 2011, 19, $279-289$.

88. Tilastokeskus. Sukupuolten tasa-arvo Suomessa 2018; Tilastokeskus, Statistics Finland: Helsinki, Finland, 2018; p. 152.

89. Sandström, V.; Kauppi, P.E.; Scherer, L.; Kastner, T. Linking country level food supply to global land and water use and biodiversity impacts: The case of Finland. Sci. Total Environ. 2017, 575, 33-40. [CrossRef] [PubMed]

90. Sandström, V.; Lehikoinen, E.; Peltonen-Sainio, P. Replacing Imports of Crop Based Commodities by Domestic Production in Finland: Potential to Reduce Virtual Water Imports. Front. Sustain. Food Syst. 2018, 2. [CrossRef]

91. Eurostat Water Statistics. Available online: https://ec.europa.eu/eurostat/web/environment/water/ database (accessed on 24 September 2018).

92. Eurostat Land Cover/Use Statistics. Available online: https://ec.europa.eu/eurostat/web/lucas/data/ database (accessed on 18 December 2018).

93. FAOSTAT Country Indicator, Finland. Available online: http://www.fao.org/faostat/en/\#country/67 (accessed on 17 December 2018).

94. Niemi, J.; Liesivaara, P.; Lehtonen, H.; Huan-Niemi, E.; Kettunen, L.; Kässi, P.; Toikkanen, H. EU:n Yhteinen Maatalouspolitiikka Vuosina 2014-2020 ja Suomen Maatalous (EU's Common Agricultural Policy during 2014-2020 and Finnish Agriculture); MTT Raportti 130; Maa- ja elintarviketalouden tutkimuskeskus (MTT): Jokioinen, Finland, 2014; p. 65.

95. Ympäristöministeriö. Kestävät Julkiset Hankinnat. Julkinen Sektori Kestävien Hankintojen Edelläkävijäksi; Ympäristöministeriö (Ministry of the environment): Edita Prima Oy: Helsinki, Finland, 2009; p. 12.

96. Finnish National Board of Education. School Meals in Finland; Finnish National Agency for Education: Helsinki, Finland, 2014; p. 2.

(C) 2019 by the authors. Licensee MDPI, Basel, Switzerland. This article is an open access article distributed under the terms and conditions of the Creative Commons Attribution (CC BY) license (http:/ / creativecommons.org/licenses/by/4.0/). 